\title{
Students' Ability and Thinking Profile in Solving Plane Problems by Provision of Scaffolding
}

\author{
Sugiyanti $1^{1)}$, Muhtarom $2^{2)}$ \\ ${ }^{1)}$ Mathematics Education Department Universitas PGRI Semarang \\ ${ }^{2}$ Mathematics Education Department Universitas PGRI Semarang \\ Corresponding author: mubtarom@upgris.ac.id
}

\begin{abstract}
This study aims to reveal thinking profile and problem solving ability of mathematics department students of Universitas PGRI Semarang in solving plane problem by providing scaffolding. Type of this study is a qualitative research. The selection of research subject is based on students' ability, feedback from lecturers and fluency both in oral or writing. Data collection technique used is Think Aloud Method. The results of the study provide an overview that after being given scaffolding, students with intermediate level of mathematics have characteristics: using the assimilation thinking process in understanding the problem, using assimilation and accommodation in planning to solve the problem. The students with lower level of mathematics, they use assimilation thinking process in understanding the problems and planning the settlement whereas they are not able to use accommodation thinking process. Students' inability in accommodation thinking process causes they can not make solution planning correctly, solve the given problems and checking the solutions. The study shows the students experienced a lot of thinking process development since they have been able to use all of information for solving the problems. The number of the given scaffolding depends on individuals and the level of students' tinking ability.
\end{abstract}

Keywords: Thingking, Problem Solving, Scaffolding

\section{Introduction}

Teachers play an important role in culture transformation through the school system, especially in managing the interaction of students with learning resources to achieve the desired learning outcomes. Thus, it is necessary for the teachers to have adequate academic and professional competence, good personality, and passion for their profession. Act No. 14 of 2005 on Teachers and Lecturers, said that teachers and lecturers must master the four competencies, those are pedagogical, personality, social, and professional competence. Professional competence is teachers' competence that is related to the ability of mastering the materials.

Hence, Mathematics Education department of Universitas PGRI Semarang need to prepare the students in order to carry out duties as a professional educator through course Mathematics for junior high school which help students mastering the material of junior high school especially plane shape topic. This is accordant with the study of Muhtarom (2012) that showed students of secondary school (SMP) whose mathematics ability is low, got the wrong answer because they experienced mistaken thinking when solving mathematical problems. This condition is strengthened by the author's 
observation when guiding students apprentice at school. The difference lies in the scope and coverage material. Mistakes made by apprentice (PPL) students in teach topic of plane should get serious attention. Therefore, the role of lecturers in teaching is to help students express thinking process in their mind, for example by asking the students tell steps in their mind. It is necessary to know the thinking errors that occured and fix the knowledge flow.

The process of tidying up the scheme or the cognitive structure of students can be done by using scaffolding cognitive support. The term has been introduced by Wood et al [1976 in Lambdin (1993)]. Wood, et al (in Anghileri, 2006) said that scaffolding was a technique assistance provided by parents to their children in according to what they had learned, which it was eventually reduced or eliminated so that the children could learn independently. Assistance provided can be tips, warnings, encouragement, problem transformination into another form that allowed students to learn by themselves. Anghileri (2006) has described that the scaffolding includes explaining, reviewing, restricting, and developing conceptual thinking. The purpose of the scaffolding was to spur the students developmental, to stimulate the creativity of students, improve the learning process, to help in developing the concept of self-esteem, to give guidance to the students, to stimulate reflection and help students achieve the learning objectives (Veeramuthu, 2011). Vygotsky also notes that through giving scaffolding, two children who have the equal level of actual developments can be differerent in their potential development level (Jones and Thornton, 1993).

Mathematical problems must be able to be solved by the students in order to maturation process and to ensure their existence both as individuals and as part of the environment. Thus, the problem-solving skills are basic skills that must be owned by a person (Kirkley, 2003) in order to make life better. Problems can not be resolved directly without involving a solving procedure and earnest effort. Problem solving is a process of problems acceptance as a challenge. In case of solving mathematical problems, one of widely known phasing is proposed by Polya (1973), which is consisted of four important steps to be done, namely:

1. Understanding the problem: includes understanding various things which are exist on problem such as given or unknown information, the conditions of the problem and whether or not the conditions are sufficient to determine the unknown things etc. At this stage, students can also make some steps needed to understand the problem, such as sketching an image, recognize the notation used, separating some parts of the requirements, etc.

2. Devising a plan: includes various efforts to find a relationship among the problems or the relationship between the data with the unknown, etc. In the end, one should choose a solution plan.

3. Carrying out the plan: includes checking every steps, whether the steps taken are correct or can be proven that the steps are correct.

4. Looking back: includes testing of the resulted solution.

The mathematics problem solving steps which is consisted of steps, strategies and self-questions in problem solving proposed by Polya can be presented in Table 1. 
Table 1. Mathematics problem solving steps by Polya

\begin{tabular}{|c|c|c|c|}
\hline No & $\begin{array}{c}\text { Problem solving } \\
\text { steps }\end{array}$ & Strategy & Self-question \\
\hline \multirow[t]{3}{*}{1.} & Understanding the & Make a sketch & What is given? \\
\hline & problem & Separate various part & What data is available? \\
\hline & & from the conditions & What is the conditions? \\
\hline \multirow[t]{2}{*}{2.} & Planning & $\begin{array}{l}\text { Find relation between } \\
\text { given data and the }\end{array}$ & $\begin{array}{l}\text { Have you ever seen the } \\
\text { relation before? }\end{array}$ \\
\hline & & unknown & $\begin{array}{l}\text { Do you know the associated } \\
\text { problem? }\end{array}$ \\
\hline \multirow[t]{2}{*}{3.} & Implementing & Check every steps & are the taken steps correct? \\
\hline & & & $\begin{array}{l}\text { Can you show that the steps is } \\
\text { corect? }\end{array}$ \\
\hline \multirow[t]{2}{*}{4.} & Reviewing & Test the result & Can you check the result? \\
\hline & & & $\begin{array}{l}\text { Can you use the result or the } \\
\text { method on the other } \\
\text { problems? }\end{array}$ \\
\hline
\end{tabular}

Based on the description, it is necessary for disclosure the students' ability and thinking profiles by providing scaffolding in solving mathematical problems, especially in plane topic.

\section{Research Method}

This research is classified as descriptive-qualitative study conducted to the Mathematics Education students of Universitas PGRI Semarang. Data resulted in the form of words, writing or numbers is obtained from the interview. Research subject selection is based on several considerations: 1) student must be communicative in order to obtain accurate data required in this study, 2) student must have taken the Mathematics for SMP courses.

The data in this study were collected by researchers directly, so that the main instrument of this study is the researcher itself who is assisted with two instruments: problem solving test instrument and task-based interview guidelines instrument. Data collection technique used was the Think Aloud Method where the students were asked to express strictly everything in their mind and asked to write directly. Analysis was conducted intensively on the ways how students solving the problem after categorizing them by their ability. Analyzing data was started by examining all available data from various sources which was from interviews, observation notes, videos etc (Moleong, 2007). The data analysis of this research is the process of searching and arranging the data obtained systematically, by reducing the data (i.e. activities of sorting process, focusing, simplification, abstraction and transformation of raw data in the field), presenting data (includes the classification and identification data i.e. writing a collection of organized and categorized data so that drawing conclusions from these data is available), drawing conclusions from the data collected and verifying the conclusion (Miles and Huberman in Sugiyono, 2008) 


\section{Results and Discussion}

Given Problem:

In a quadrilateral $\mathrm{ABCD}$, the angle $\mathrm{ABC}$ and the angle $\mathrm{DAC}$ is right angles. The circumference of $A B C D$ is $64 \mathrm{~cm}$, circumference of $A B C$ is $24 \mathrm{~cm}$, and the circumference of $\mathrm{ACD}$ is $60 \mathrm{~cm}$. Determine the area of quadrilateral $\mathrm{ABCD}$ ?

Subjects in this study are students with three mathematics ability level: high, medium and low. The results showed that the high level students do not require scaffolding in solving the problem, they have been able to understand the problem, arrange planning, execute the plan properly and give arguments on every steps implemented. In understanding the problem subjects use the assimilation thinking process, in arranging the plans they use assimilation and accommodation thinking process. The assimilation thinking process can be identified when the subject can expain the prerequisites material, can instantly make a relation between the area of quadrilateral $\mathrm{ABCD}$, the triangle $\mathrm{ABC}$ and triangle $\mathrm{ACD}$ based on sketch created. Meanwhile the accommodation thinking process can be seen when subjects find the relationship between the area of triangle $\mathrm{ABC}$ and $\mathrm{ACD}$ with Pythagorean theorem and equations derived from the relationship between the area of quadrilateral $A B C D$, the triangle $A B C$ and triangle ACD. In executing the plan and re-checking the solution, subjects use assimilation thingking process. Results and discussion of students thinking profile for intermediate and lower level mathematics subjects will be discussed below.

\section{Subject with Intermediate level of mathematics ability (Subject VN)}

Subject VN is a subject with an intermediate mathematics ability. In solving mathematical problems, the subject $\mathrm{VN}$ can represent the information in sketches correctly but $\mathrm{VN}$ was not able to make the relation among the circumference of quadrilateral $\mathrm{ABCD}$, triangle $\mathrm{ABC}$, triangle $\mathrm{ACD}$ and the right angle. The inability of the subject in making connection cause the subject cannot construct mathematical model from the given problem. Subject experienced a 'deadlocked' in thinking because there is only one equation that includes five different variables. This means the subject can not provide a justification for each steps of solution and the subject does not understand accurately the structures involved in the problem.

After being given the scaffolding, the thinking process of subject $\mathrm{VN}$ grows accordingly with the plot of problem solving. The subject $\mathrm{VN}$ can use assimilation and accommodation thinking processes so VN can handle the difficulties previously experienced and solve the problem. It shows that the subject VN experiences a lot of thingking process growth because he was able to use all the information available on the issue to be used in solving the problem. 
The general concept of the subject VN thinking process in solving the problem can be presented in Diagram 1 below:

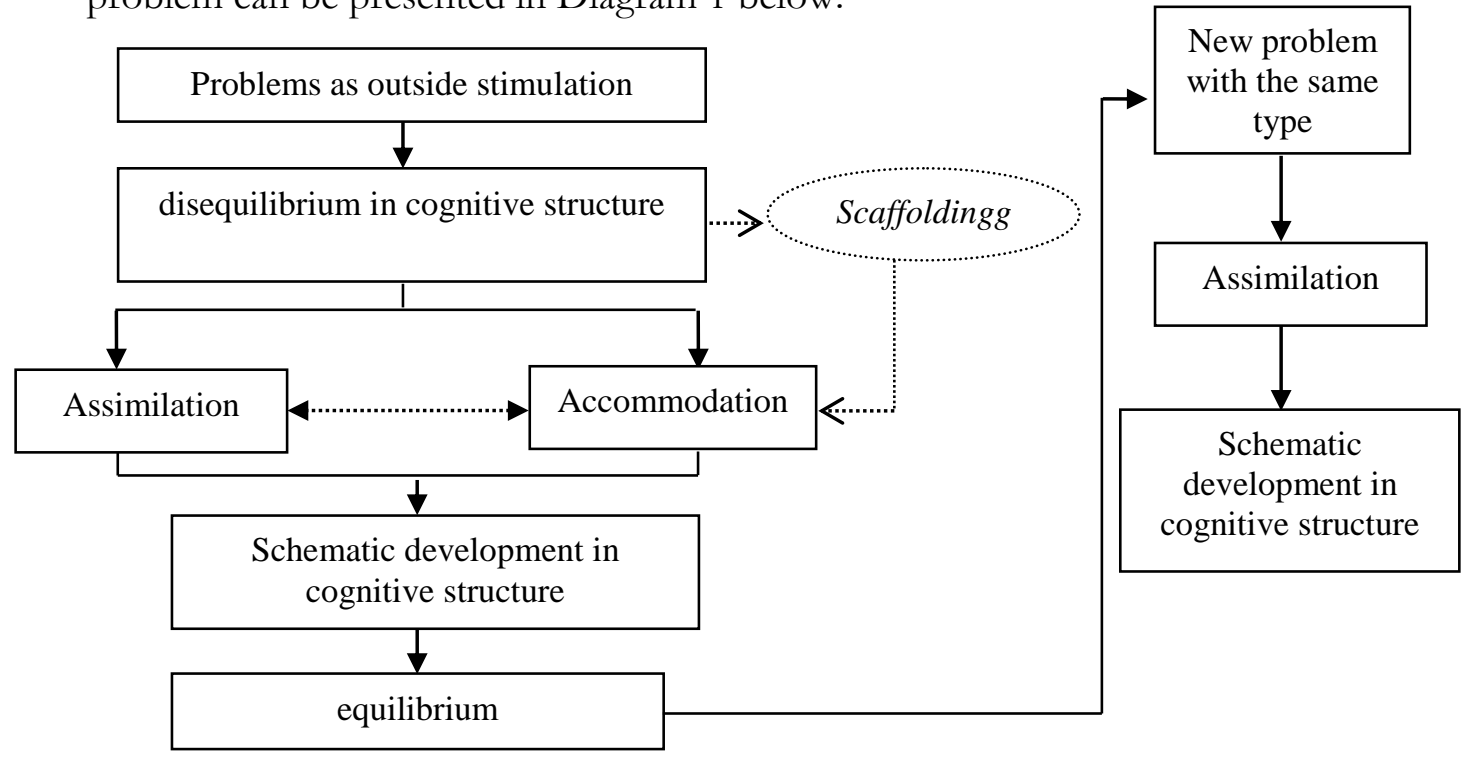

Diagram 1. Subject VN thinking process in Accommodation framework

Table 2. Subject VN's ability and thinking profile

\begin{tabular}{|c|c|c|}
\hline $\begin{array}{l}\text { Problem Solving } \\
\text { steps }\end{array}$ & $\begin{array}{l}\text { Subject VN's thinking profile } \\
\text { Before providing Scaffolding }\end{array}$ & $\begin{array}{l}\text { Subject VN's thinking profile } \\
\text { After providing Scaffolding }\end{array}$ \\
\hline $\begin{array}{l}\text { Understanding the } \\
\text { problem }\end{array}$ & $\begin{array}{l}\text { - clear in sketching an image of } \\
\text { the given problem } \\
\text { - clear in mentioning what is } \\
\text { known and what is asked in } \\
\text { the problem } \\
\text { - clearly determine whether the } \\
\text { information is enough or not } \\
\text { to answer the questions }\end{array}$ & $\begin{array}{l}\text { - clear in sketching an image of } \\
\text { the given problem } \\
\text { - clear in mentioning what is } \\
\text { known and what is asked in the } \\
\text { problem } \\
\text { - clearly determine whether the } \\
\text { information is enough or not } \\
\text { to answer the questions }\end{array}$ \\
\hline Planning the solution & $\begin{array}{l}\text { - Subject can not make directly } \\
\text { the solution plan because to } \\
\text { find the area of ABCD, the } \\
\text { subject must find length of the } \\
\text { side of triangle ABC and } \\
\text { triangle ACD. } \\
\text { - Subject understand the } \\
\text { problem but can not mention } \\
\text { any other knowledge that can } \\
\text { be employed to solve } \\
\text { problems } \\
\text { - can not make the connection } \\
\text { between the area of } \\
\text { quadrilateral ABCD, the } \\
\text { triangle ABC and triangle } \\
\text { ACD based on the sketch } \\
\text { made } \\
\text { * Surrender, can not make }\end{array}$ & $\begin{array}{l}\text { - Subject can not make directly } \\
\text { the solution plan because to } \\
\text { find the area of ABCD, the } \\
\text { subject must find length of the } \\
\text { side of triangle ABC and } \\
\text { triangle ACD. } \\
\text { - Subject understand the } \\
\text { problem and can mention } \\
\text { other knowledge that can be } \\
\text { used to solve problems } \\
\text { - can determine the relationship } \\
\text { between the area } \\
\text { quadrilateral ABCD, the } \\
\text { triangle ABC and triangle ACD } \\
\text { based on the sketch made } \\
\text { - make the connection between } \\
\text { the area of a triangle ABC with } \\
\text { Pythagorean theorem and } \\
\text { equations derived from the }\end{array}$ \\
\hline
\end{tabular}




\begin{tabular}{|c|c|c|}
\hline $\begin{array}{l}\text { Problem Solving } \\
\text { steps }\end{array}$ & $\begin{array}{l}\text { Subject VN's thinking profile } \\
\text { Before providing Scaffolding }\end{array}$ & $\begin{array}{l}\text { Subject VN's thinking profile } \\
\text { After providing Scaffolding }\end{array}$ \\
\hline & settlement plan) & $\begin{array}{l}\text { relationship among the area of } \\
\text { quadrilateral ABCD, the } \\
\text { triangle ABC and triangle } \\
\text { ACD. } \\
\text { - make the connection between } \\
\text { the area of a triangle ADC with } \\
\text { Pythagorean theorem and } \\
\text { equations derived from the } \\
\text { relationship among the area of } \\
\text { quadrilateral ABCD, the } \\
\text { triangle ABC and triangle } \\
\text { ACD. } \\
\text { - to find the area of quadrilateral } \\
\text { ABCD, the subject will add the } \\
\text { area of triangle ABC to the } \\
\text { area of triangle ACD. }\end{array}$ \\
\hline Implementing the plan & * (Can not solve the problem) & $\begin{array}{l}\text { Subject can implement the plan } \\
\text { fluently, can answer the issue } \\
\text { properly based on problem } \\
\text { solving steps that have been } \\
\text { arranged and perform calculation } \\
\text { algorithm correctly }\end{array}$ \\
\hline rechecking & * (Does not recheck) & $\begin{array}{l}\text { Subject is sure about the results } \\
\text { obtained by reviewing steps and } \\
\text { calculations performed }\end{array}$ \\
\hline
\end{tabular}

\section{Conclusion:}

The characteristics of subject VN before being given a scaffolding are: in understanding the problem VN uses the thinking process of assimilation, in planning the settlement of problem VN experiences disfluency of think assimilation that is when VN is unable to make the connection between the area of quadrilateral ABCD, the triangle ABC and triangle ACD based on sketch made. Disfluency in think assimilation causes the subject VN can not make the settlement plan and solve the problem.

The characteristics of subject VN after being given a scaffolding are: in understanding the problem VN uses the thinking process of assimilation, in planning the settlement of problem $\mathrm{VN}$ uses the thinking process of assimilation and accommodation. The thinking process of assimilation can be identified when $\mathrm{VN}$ can mention the material prerequisites, can directly make the connection between the area of quadrilateral $\mathrm{ABCD}$, the triangle $\mathrm{ABC}$ and triangle ACD based on sketch made. While the thinking process of accommodation is seen when the subject VN looks for the relationship between the area of the triangle ABC and ACD with Pythagorean theorem and equations derived from the relationship among the area of quadrilateral $\mathrm{ABCD}$, the triangle $\mathrm{ABC}$ and triangle $\mathrm{ACD}$. In implementing the settlement plan and review the solution, the subject VN uses the thinking process of assimilation. 


\section{Subject with lower level of mathematics ability (Subject DW)}

Subject DW is a subject with lower level of mathematics ability. In solving mathematical problems given, subject DW was not able to represent the information in the sketches correctly of a given problem. Subject DW was not able to make relation among the circumference of quadrilateral $\mathrm{ABCD}$, triangle $\mathrm{ABC}$, triangle ACD and right angle. The inability of the subject in making connection caused the subject could not make the mathematical model of the problem. Subjects experienced a 'deadlocked' thinking when solving the problem. This means that the subject can not provide a justification for each steps of completion of a given problem and the subject does not understand clearly the structures involved in the problem.

After being given the scaffolding, the thinking process of subject DW evolved accordingly with the plot of problem solving. Subject DW then could use the thinking process of assimilation so that DW could make the relationship between the area of quadrilateral $\mathrm{ABCD}$, the triangle $\mathrm{ABC}$ and triangle $\mathrm{ACD}$ based on sketch made. But after that, the subject of DW was still unable to find the relationship between the area of the triangle $\mathrm{ABC}$ and $\mathrm{ACD}$ with Pythagorean theorem and equations derived from the relationship among area of quadrilateral $A B C D$, the triangle $\mathrm{ABC}$ and triangle ACD. Disfluency in thinking accommodation caused the subject DW was unable to make the settlement plan and solve the problem.

The general concept of thinking process of subject DW is presented in Diagram 2 below.

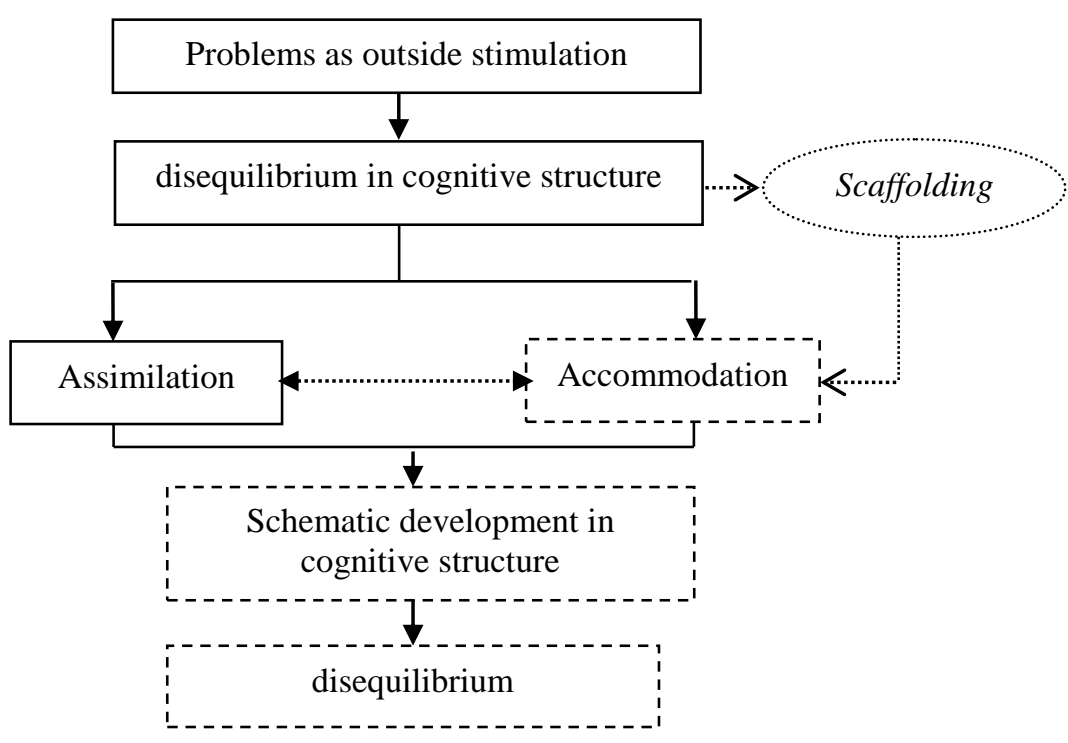

Diagram 2. Thinking Process of Subject DW in Accommodation Framework 
Table 3. Thinking profile and ability of Subject DW

\begin{tabular}{|c|c|c|}
\hline $\begin{array}{c}\begin{array}{c}\text { Problem Solving } \\
\text { steps }\end{array} \\
\end{array}$ & $\begin{array}{l}\text { Subject DW's thinking profile } \\
\text { Before providing Scaffolding }\end{array}$ & $\begin{array}{l}\text { Subject DW's thinking profile } \\
\text { After providing Scaffolding }\end{array}$ \\
\hline $\begin{array}{l}\text { Understanding the } \\
\text { problem }\end{array}$ & $\begin{array}{l}\text { - mistake in sketching an image } \\
\text { of the given problem } \\
\text { - clear in mentioning what is } \\
\text { known and what is asked in } \\
\text { the problem } \\
\text { - clearly determine whether the } \\
\text { information is enough or not } \\
\text { to answer the questions }\end{array}$ & $\begin{array}{l}\text { - clear in sketching an image of } \\
\text { the given problem } \\
\text { - clear in mentioning what is } \\
\text { known and what is asked in the } \\
\text { problem } \\
\text { - clearly determine whether the } \\
\text { information is enough or not } \\
\text { to answer the questions }\end{array}$ \\
\hline Planning the solution & $\begin{array}{l}\text { - Subject can not make directly } \\
\text { the solution plan because to } \\
\text { find the area of ABCD, the } \\
\text { subject must find length of the } \\
\text { side of triangle ABC and } \\
\text { triangle ACD. } \\
\text { - Subject does not understand } \\
\text { the problem but can not } \\
\text { mention any other knowledge } \\
\text { that can be employed to solve } \\
\text { problems conection } \\
\text { - can not make the connection } \\
\text { between the area of } \\
\text { quadrilateral ABCD, the } \\
\text { triangle ABC and triangle } \\
\text { ACD based on the sketch } \\
\text { made not make } \\
\text { * (Surrender, can not } \\
\text { settlement plan) }\end{array}$ & $\begin{array}{l}\text { - Subject can not make directly } \\
\text { the solution plan because to } \\
\text { find the area of ABCD, the } \\
\text { subject must find length of the } \\
\text { side of triangle ABC and } \\
\text { triangle ACD. } \\
\text { - Subject understand the } \\
\text { problem and can mention } \\
\text { other knowledge that can be } \\
\text { used to solve problems } \\
\text { - can determine the relationship } \\
\text { between the area of } \\
\text { quadrilateral ABCD, the } \\
\text { triangle ABC and triangle ACD } \\
\text { based on the sketch made } \\
\text { - can not make the connection } \\
\text { between the area of a triangle } \\
\text { ABC with Pythagorean } \\
\text { theorem and equations derived } \\
\text { from the relationship among } \\
\text { the area of quadrilateral } \\
\text { ABCD, the triangle ABC and } \\
\text { triangle ACD. } \\
\text { - Can not make the connection } \\
\text { between the area of a triangle } \\
\text { ADC with Pythagorean } \\
\text { theorem and equations derived } \\
\text { from the relationship among } \\
\text { the area of quadrilateral } \\
\text { ABCD, the triangle ABC and } \\
\text { triangle ACD. }\end{array}$ \\
\hline Implementing the plan & * (Can not solve the problem) & $\begin{array}{l}\text { - correct in finding a relationship } \\
\text { between the area of } \\
\text { quadrilateral ABCD, the } \\
\text { triangle } A B C \text { and triangle ACD } \\
\text { based on sketch made. } \\
\text { * (Can not solve the problem) }\end{array}$ \\
\hline rechecking & * (Does not recheck) & * (Does not recheck) \\
\hline
\end{tabular}




\section{Conclusion:}

The characteristics of subject DW before being given a scaffolding are: in understanding the problem DW uses the thinking process of assimilation, in planning the settlement of problem DW experiences disfluency of think assimilation that is when DW is unable to make the connection between the area of quadrilateral $\mathrm{ABCD}$, the triangle $\mathrm{ABC}$ and triangle $\mathrm{ACD}$ based on sketch made. Disfluency in think assimilation causes the subject DW can not make the settlement plan and solve the problem.

The characteristics of subject DW after being given a scaffolding are: in understanding the problem DW uses the thinking process of assimilation, in planning the settlement of problem DW uses the thinking process of assimilation. The thinking process of assimilation can be identified when DW can mention the material prerequisites, can directly make the connection between the area of quadrilateral $\mathrm{ABCD}$, the triangle $\mathrm{ABC}$ and triangle $\mathrm{ACD}$ based on sketch made. However the subject DW is unable to do thinking process of accommodation that is the inability of subject DW in finding the relationship between the area of the triangle $A B C$ and ACD with Pythagorean theorem and equations derived from the relationship among the area of quadrilateral $A B C D$, the triangle $A B C$ and triangle $A C D$. Inability of Subject DW to think accomodation causes DW makes mistake in making settlement plan, can not finish of solving problem and does not conduct reviewing of the result

In general, results of this study consistent with previous studies (Banton et al, 2003; Peretz, 2006; Simon \& Klein, 2007; Broza, 2010; Santosa, et al, 2013; Fauzy, 2015; Sari, et al, 2016). The provision of scaffolding can improve the attitude of reasoning from the perspective of elementary school mathematics teacher (Peretz, 2006). Furthermore, Broza (2010), the teacher provides scaffolding of transformation of mathematics discourse as a good strategy to enhance students' understanding of mathematical ability in understanding the basic concept. Fauzy (2015) concludes that students' thinking process in problem solving is unique. Almost all students have difficulty in step of using mathematical concepts which is previously learned, while difficulties in understanding the problem are only experienced by the students with lower mathematics ability. Provision of scaffolding based on students' necessity can improve their thinking process. Meanwhile, Sari, et al (2016) describes the provision of scaffolding can handle students' mathematical reasoning difficulties so teachers can give it to students effectively to overcome that difficulties and enhance students' capabilities. To conclude, educators should provide scaffolding as assistance for students individually to overcome their difficulties and enhance their capabilities.

\section{Conclusion}

According to the results of research and discussion, this study can be concluded as follows: Students with intermediate mathematical ability, the characteristics before they are given scaffolding: to understand the problem they use thinking process of assimilation, to prepare plans for solving the problem they experience disfluency of thinking assimilation that is when they are not able to make the connection between the area of quadrilateral $\mathrm{ABCD}$, the triangle $\mathrm{ABC}$ and triangle $\mathrm{ACD}$ based on sketch made. The disfluency then cause the student cannot make the settlement plan and they are unable to resolve a given problem. After being provided the scaffolding: to understand the problem they conduct thinking process of assimilation, to prepare plans for solving problems use the thinking process of assimilation and accommodation. The thinking process of assimilation can be identified when the students can mention the prerequisites material, can instantly make a connection between the area of quadrilateral $A B C D$, the triangle $\mathrm{ABC}$ and triangle $\mathrm{ACD}$ based on sketch made. While the thinking process of 
accommodation is seen when students find the relationship between the area of triangle $\mathrm{ABC}$ and $\mathrm{ACD}$ with Pythagorean theorem and equations derived from relationship among the area of quadrilateral $\mathrm{ABCD}$, triangle $\mathrm{ABC}$ and triangle $\mathrm{ACD}$. In implementing the settlement plan and re-examining the result, students use the thinking process of assimilation.

Students with lower mathematical ability, the characteristics before they are given scaffolding: to understand the problem they use thinking process of assimilation, to prepare plans for solving the problem they experience disfluency of thinking assimilation that is when they are not able to make the connection between the area of quadrilateral $\mathrm{ABCD}$, the triangle $\mathrm{ABC}$ and triangle $\mathrm{ACD}$ based on sketch made. The disfluency then cause the student cannot make the settlement plan and they are unable to resolve a given problem. After being provided the scaffolding the characteristics of students: to understand the problem they conduct thinking process of assimilation, to prepare plans for solving problems use the thinking process of assimilation when the students can mention the prerequisites material, can instantly make a connection between the area of quadrilateral $\mathrm{ABCD}$, the triangle $\mathrm{ABC}$ and triangle $\mathrm{ACD}$ based on sketch made. While the thinking process of accommodation is seen when students find the relationship between the area of triangle $\mathrm{ABC}$ and $\mathrm{ACD}$ with Pythagorean theorem and equations derived from relationship among the area of quadrilateral $\mathrm{ABCD}$, triangle $\mathrm{ABC}$ and triangle ACD. In implementing the settlement plan and re-examining the result, students use the thinking process of assimilation. However the students are unable to do thinking process of accommodation that is the inability of students in finding the relationship between the area of the triangle $\mathrm{ABC}$ and $\mathrm{ACD}$ with Pythagorean theorem and equations derived from the relationship among the area of quadrilateral $A B C D$, the triangle $A B C$ and triangle ACD. Inability of thinking accomodation causes students make mistake in making settlement plan, can not finish of solving problem and does not conduct reviewing of the result.

\section{Bibliography}

Anghileri, J. (2006). Scaffolding Practices that Enhance Mathematics Learning. Journal of Mathematics Teacher Education. 9: 33-52.

Blanton, Maria L.; Stylianou, Despina A.; David, Maria Manuela. (2003). International Group for the Psychology of Mathematics Education, Paper presented at the 27th International Group for the Psychology of Mathematics Education Conference Held Jointly with the 25th PME-NA Conference (Honolulu, HI, Jul 13-18, 2003), v2 p113-120.

Broza, O \& Ben, Y. (2010). The Effect of Using a Video Clip Presenting a Contextual Story on Low-Achieving Students' Mathematical Discourse. Educational Studiesin Mathematics.

Fauzy, Mohamad Irfan. (2015). Proses Berpikir Siswa dalam Pemecahan Masalah dengan Pemberian Scaffolding. Seminar Nasional Matematika dan Pendidikan Matematika UNY. ISBN. 978-602-73403-0-5. hal 1041-1046

Jones, G. A., \& Thornton, C.A. (1993). Vygotsky revisited: Nurturing young children's understanding of number. Focus on Learning Problems in Mathematics. 15 $(2 \& 3): 18-28$.

Kirkley, J., (2003), Principle for Teaching Problem Solving, Technical Paper, Plato Learning Inc. 
Lambdin, D.V. (1993). 'Monitoring moves and roles in cooperative mathematical problem solving'. Focus on Learning Problems in Mathematics. 15 (2\&3): 18-28.

Muhtarom . (2012). Proses Berpikir Siswa IX Berkemampuan Matematika Rendah Sekolah Menengah Pertama dalam Memecahkan Masalah Matematika. Makalah Seminar Nasional Matematika di Universitas Sebelas Maret Surakarta tanggal 6 Oktober 2012.

Peretz. D. (2006). Enhancing Reasoning Attitudes of Prospective Elementary School Mathematics Teachers. Journal of Mathematics Teacher Education (2006) 9:38140 .

Polya. (1973). How to Solve It. 2nded, Princeton University Press, ISBN 0-691-08097-6.

Sari, Nur Indha Permata; dkk . (2016). Diagnosis Kesulitan Penalaran Matematis Siswa Dalam Menyelesaikan Masalah Pola Bilangan Dan Pemberian Scaffolding. Makalah Konferensi Nasional Penelitian Matematika dan Pembelajarannya (KNPMP I). ISSN: 2502-6526. 285-394.

Santosa, Nurhadi; dkk (2013). Kemampuan Pemecahan Masalah pada Pembelajaran Matematika dengan Strategi Master dan Penerapan Scaffolding. Unnes Journal of Mathematics Education Research. ISSN 2252-6455, 2 (2): 69-75.

Simons, K.D. \& Klein, J.D. (2007). The Impact of Scaffolding and Student Achievement Levels in a Problem-based Learning Environment. Instructional Science (2007) Volume 35, Issue 1, pp 41-72.

Sugiyono, (2008). Metode Penelitian Pendidikan Pendekatan Kuantitatif, Kualitatif, dan R\&D. Bandung: Alfabeta.

Veeramuthu, A., Veerappan, L., Suan, W. A., \& Sulaiman, T. (2011). The effect of scaffolding technique in journal writing among the second language learners. Journal of Language Teaching and Research. 2(4): 934-940. 